\title{
SOSIALISASI PEMBUATAN PENYEDAP RASA ALTERNATIF DI DESA JANTI SIDOARJO
}

\author{
Sari Cahyaningtias'), Debora Martsacanita ${ }^{2)}$, Nona Fitria ${ }^{3)}$ \\ 1,2,3Fakultas Keguruan dan Ilmu Pendidikan, Universitas PGRI Adi Buana Surabaya \\ Email: sari@unipasby.ac.id ${ }^{1},{ }^{2}$ dera.debora@yahoo.com,nonafitria11@gmail.com ${ }^{3}$
}

\begin{abstract}
Abstrak
Monosodium Glutamate (MSG) umumnya dikenal sebagai micin/vetsin atau penyedap rasa yang banyak digunakan sebagai penambah rasa gurih pada makanan-makanan secara luas. Penggunaan MSG secara berlebih dan berkelanjutan ini dapat meningkatkan kadar garam dalam tubuh dan juga dapat menyebabkan berbagai jenis penyakit, seperti pusing, gatal-gatal, hipertensi, gagal ginjal, dan obesitas. MSG dapat diganti dengan penyedap alami yang memiliki rasa lebih nikmat dan menyehatkan. Pada program pengabdian ini diperkenalkan penyedap rasa alternatif berbahan baku daging ayam. Penggunaan daging ayam sebagai bahan dasar MSG di Desa Janti, Sidaorjo dikarenakan ketersediaan bahan baku yang cukup besar dan dapat dijangkau oleh seluruh lapisan masyarakat. Daging ayam sendiri mengandung protein yang baik untuk kesehatan. Sosialisasi pembuatan penyedap rasa di Desa Janti melibatkan ibu-ibu PKK dan perangkat desa. Antusiasme dari sosialisasi ini terlihat dari keaktifan tiap-tiap peserta. Program lanjutan dilakukan oleh pada ibu-ibu PKK Desa Janti secara mandiri berbekal pengetahuan yang telah didapat dari sosialisasi dan dibantu oleh perangkat desa.
\end{abstract}

Kata kunci: daging ayam, penyedap rasa, makanan sehat, $M S G$

\begin{abstract}
Monosodium Glutamate (MSG) is seasoning which is widely used as a savory enhancer in foods. The excessive and sustained use of MSG can increase salt levels in the body and can also cause various types of diseases, such as dizziness, hives, hypertension, kidney failure, and obesity. MSG can be replaced with natural flavorings that have a more delicious and healthy taste. In this community service program, the alternative flavorings is made from raw chicken meat. The chicken is easy to find in Janti Village, Sidoarjo and affordable by all levels of society. The Chicken itself contains good protein for health. The socialization of making flavoring in the village of Janti involved a local organization namely Ibu-ibu PKK and officials. Those participants were enthusiast and impressed by our program. Further action is following up the program and spreading out to others in Desa Janti independently. The plan will be handed by officers based on ibu-ibu PKK's knowledge from previous socialization.
\end{abstract}

Keywords: Chicken, chicken broth, healthy food, Monosodium Glutamates 


\section{PENDAHULUAN}

$\begin{array}{lr}\text { Seiring } & \text { dengan perkembangan } \\ \text { kehidupan } & \text { bermasyarakat, berbagai }\end{array}$ kebutuhan terus berkembang dan semakin kompleks misalnya kebutuhan makanan. Konsumen memiliki kecenderungan untuk memilih makanan yang enak dan lezat. Tren ini mendorong produsen makanan untuk memproduksi makanan lezat secara cepat salah satunya dengan penambahan produk penyedap rasa yang lebih dikenal dengan produk vetsin (Monosodium glutamate). MSG memberikan aroma khas "umami" yang diakui sebagai aroma dasar kelima yang sangat mirip dengan aroma daging atau aroma kaldu. Dalam peraturan menteri kesehatan tahun 1976 juga telah mengidentifikasi bahwa penyedap rasa, pewarna, dan aroma, pemantap, antioksidan, pengawet, pengemulsi, anti gumpal, pematang, pemucat dan pengenta termasuk salah satu bahan tambahan yang digunakan untuk peningkatan mutu dan rasa pada makanan.

MSG yang berlebihan dapat menyebabkan rasa pusing dan mual yang disebut juga Chinese Restaurant Syndrome. Garam dalam MSG mampu memenuhi kebutuhan garam sebanyak 20-30\%, sehingga konsumsi MSG yang berlebihan menyebabkan kenaikan kadar garam dalam darah (Lisdiana, 2004). Selain itu, peggunaan MSG secara berlebih juga dapat berakibat buruk pada kesehatan, seperti: kerusakan sel saraf, asma, obesitas, hipertensi, merusak sel, dan kerusakan ginjal dan depresi.

Penggunaan MSG disarankan agar sesuai dengan kebutuhan dan disarankan memakai bumbu alami yang lebih sehat, dari permasalahan diatas kami sepakat untuk membuat program pengabdian "Pembuatan Kaldu bubuk pengganti MSG" yang kami harapkan jadi inspirasi untuk Masyarakat
Desa Janti untuk hidup lebih sehat dan mengurangi konsumsi MSG, program kami bertujuan untuk menggantikan penyedap rasa instan (MSG) dengan kaldu bubuk alami yang berbahan dasar bumbu alami.

Penyedap rasa pengganti MSG telah banyak ditawarkan dengan bahan-bahan sehat lain. Tahun 2018 Malichati dan Adi membuat penelitian tentang tepung hati ayam sebagai pengganti kaldu ayam instan. Hati ayam ini dipilih karena dapat mencegah anemia bagi konsumennya. Produk modifikasi kaldu ayam instan dengan substitusi tepung hati ayam unggul pada kandungan protein dan zat besi yang lebih tinggi dibandingkan produk komersial serupa (Malichati dan Adi, 2018).

Penelitian lain alternatif pembuatan penyedap rasa non MSG juga dilakukan oleh Palupi dkk pada tahun 2015. Penyedap rasa non MSG berbahan alami salah satunya yaitu jamur merang segar. Jamur merang sendiri memiliki kandungan protein sebesar $16.9 \mathrm{~g} / 100 \mathrm{~g}$ dan asam glutamate $4.0428 \mathrm{~g} / 100 \mathrm{~g}$ sehingga baik untuk penyedap rasa.

Berdasarkan kebutuhan produk makanan yang enak dan bergizi, maka pada program pengabdian pada masyarakat kali ini dilakukan sosialisasi pembuatan penyedap rasa alternatif dari bahan alami. Pemilihan daging ayam sebagai bahan alami karena tingkat kemudahan bahan baku di lingkungan Desa Janti. Kebutuhan akan makanan enak dan sehat oleh ibu-ibu rumah tangga juga menjadi faktor pendorong dalam pemilihan tema ini.

\section{TINJAUAN PUSTAKA}

Masyarakat saat ini umumnya masih beranggapan bahwa MSG tidak baik bagi kesehatan karena banyak kabar yang menyebutkan berbagai resiko akibat mengkonsumsinya. Monosodium glutamat, 
juga dikenal sebagai sodium glutamat atau MSG, merupakan garam natrium dari asam glutamat yang merupakan salah satu asam amino non-esensial paling berlimpah yang terbentuk secara alami. MSG telah digunakan secara aman selama lebih dari 100 tahun untuk membumbui makanan. Selama jangka waktu ini, banyak penelitian telah dilakukan untuk memperjelas peranan, manfaat, dan keamanan MSG. Pada saat ini, badan-badan internasional dan nasional untuk keamanan zat tambahan makanan menganggap MSG aman untuk dikonsumsi manusia sebagai penguat cita rasa Sebuah laporan dari Federation of American Societies for Experimental Biology (FASEB) yang disusun pada tahun 1995 atas nama United States Food and Drug Administration (FDA) menyimpulkan bahwa $M S G$ aman bila "dikonsumsi pada tingkat yang sesuai" dan meskipun tampaknya ada subkelompok orang yang terlihat sehat yang mengalami reaksi berupa sindrom kompleks $M S G$ saat diberi 3 g MSG tanpa makanan, sebab akibat oleh $M S G$ belum ditetapkan karena daftar sindrom kompleks $M S G$ didasarkan pada laporan testimoni.

Penyedap rasa alternatif ini dibuat dari bahan-bahan alami yang bergizi tanpa meninggalkan tujuan utama pelezat makanan instan. Tingginya kebutuhan akan makanan yang lebih lezat dan tetap sehat untuk dikonsumsi mendorong dibuatnya kaldu bubuk pengganti MSG dengan bahan dasar daging ayam. Alasan mengapa kita menggunakan daging ayam dikarenakan selain mudah didapatkan di pasar, daging ayam juga mengandung protein yang baik untuk kesehatan. Mengonsumsi kaldu ayam sebagai penyedap masakan ternyata juga sangat baik untuk kesehatan. Dalam 100 gram daging ayam mengandung kalori 302 kal; protein 18,2 gram; lemak 25,0 gram; kalsium $14 \mathrm{mg}$; fosfor $200 \mathrm{mg}$; dan besi 1,5 mg.

Selain sebagai sumber protein, daging ayam juga menghasilkan kalori, namun berbeda dengan daging hewan konsumsi lainnya, daging ayam memiliki jumlah kalori yang lebih rendah. Daging ayam dapat dipakai sebagai bahan makanan yang baik untuk mengendalikan pertambahan berat badan dan cocok bagi yang sedang melakukan program diet, berguna membantu penyembuhan dari penyakit dan sebagai bahan nutrisi para lansia. Ayam yang merupakan jenis unggas adalah yang paling banyak dikonsumsi oleh masyarakat, khususnya di Indonesia. 2 jenis ayam yang biasa dikonsumsi yaitu ayam ras (broiler) dan ayam lokal (buras/kampung). Kedua jenis ayam ini menjadi sumber protein hewani.

\section{METODE PELAKSANAAN}

Lokasi sosialisasi pembuatan kaldu pengganti MSG dilakukan di balai desa Janti pada tanggal 7 Februari 2019 dan diikuti oleh peserta ibu-ibu PKK. Berikut adalah alat dan bahan yang diperlukan untuk pembuatan Penyedap Rasa Alternatif, yakni:

\section{Alat dan bahan}

Bahan-bahan dalam pembuatan produk penyedap rasa alternatif ini adalah Ayam fillet 300gr, Bawang Bombay 1 buah, Bawang putih 15 siung, Daun bawang 1 batang, Seledri 2 batang, dan Wortel 100 gram, Garam 2 sdm. Peralatan yang digunakan dalam program sosialisasi adalah Teflon, Spatula kayu, Oven, Loyang, Pisau, Talenan, Blender dan ayakan. Tahap pembuatan dimulai dari pembuatan pasta kaldu ayam terlebih dahulu, kemudian selanjutnya kaldu ayam instan bubuk.

\section{Pembuatan Pasta kaldu ayam}

Langkah pertama dalam pembuatan pasta kaldu ayam ini adalah mencuci bersih semua bahan yang diperlukan kemudian 
haluskan semua bahan dengan menggunakan blender. Mengusahakan untuk tidak menambahkan air. Jika bahan sulit untuk dihaluskan, maka dapat menambahkan 1-2 sdm minyak untuk mempermudah proses penghalusan. Semua bahan benar-benar halus. Selanjutnya, Pasta kaldu dimasak dengan menggunakan wajan anti lengket. Aduk-aduk selama 20-30 menit untuk mengurangi kandungan airnya. Pada tahap ini, penyedap rasa alternatif yang dihasilkan berbentuk pasta dan siap digunakan. Proses penyimpanan Memasukkan penyedap rasa bubuk yang dihasilkan dalam kemasan tertutup dan disimpan dalam lemari es. Pasta penyedap rasa ini dapat bertahan 3 sampai 4 minggu setelah pemakaian pertama.

\section{Pembuatan penyedap rasa bubuk}

Untuk mendapatkan masa pakai yang lebih lama pasta penyedap rasa dapat dilakukan pengolahan lebih lanjut. Langkah lanjutan adalah meratakan pasta kaldu di atas Loyang kemudian dipanggang sekitar 30 menit pada suhu $150^{\circ} \mathrm{C}$ atau sampai agak kering. Jika sudah hampir kering, keluarkan kaldu bubuk setengah jadi dinginkan. Kemudian blender kaldu tersebut untuk mendapatkan bubuk yang lebih halus. Selanjutnya panggang kembali hingga benarbenar kering dan blender sekali lagi untuk menjadi bubuk kaldu. Langkah terakhir adalah mengayak bubuk kaldu yang dihasilkan sehingga mendapatkan tekstur yang halus.

\section{Hasil Pelaksanaan}

Lokasi pelaksanaan sosialisasi pembuatan penyedap rasa alternatif di balai desa Janti, Kecamatan Tulangan, Sidoarjo. Sosialisasi ini melibatkan 30 ibu-ibu PKK dari 2 dusun: Dusun Kerajan dan Dusun Kedung Turi.

Warga Desa Janti, umumnya, sangat bergantung pada penyedap rasa instan dalam proses pengolahan masakan. Kurang kepedulian terhadap bahaya kandungan MSG secara terus-menerus dan kurangnya pengetahuan tentang bahan alami lain pengganti MSG ini adalah faktor utama penyebab warga Desa Janti setia terhadap produk penyedap rasa instan.

Pelaksanaan program pengabdian ini diawali dengan pemaparan mengenai bahaya penyedap rasa bagi kesehatan dan bahanbahan yang diperlukan. Diharapkan berbekal informasi yang diberikan ibu-ibu Desa Janti akan lebih berhati-hati dalam memilih makanan untuk dikonsumsi oleh anggota keluarga.

Pelaksanaan program diikuti dengan survei kebermanfaat kegiatan sosialisasi kepada warga Desa Janti yang berpartisipasi. Mayoritas peserta berpendapat bahwa informasi yang diberikan sangat mudah dipahami dan dapat dipraktikkan secara mandiri, mengingat bahan-bahan sangat mudah didapatkan dan proses pembuatan yang cukup mudah.

Program pengabdian ini berlangsung efektif karena masyarakat di desa Janti tergolong masyarakat yang antusias dalam mengikuti program terutama ibu-ibu PKK di desa Janti. Hal ini didukung dengan adanya ide-ide kreatif dari peserta sosialisasi berkaitan dengan bahan alami lain yang mungkin digunakan seperti daging ikan lele, daging ikan bandeng, dan jamur. Kemungkinan untuk pembuatan penyedap rasa alami secara masal juga disampaikan oleh perangkat Desa Janti sebagai program lanjutan dari hasil sosialisasi.

Berikut merupakan foto-foto kegiatan saat pelaksanaan dalam kegiatan sosialisasi pembuatan penyedap rasa alternatif. 


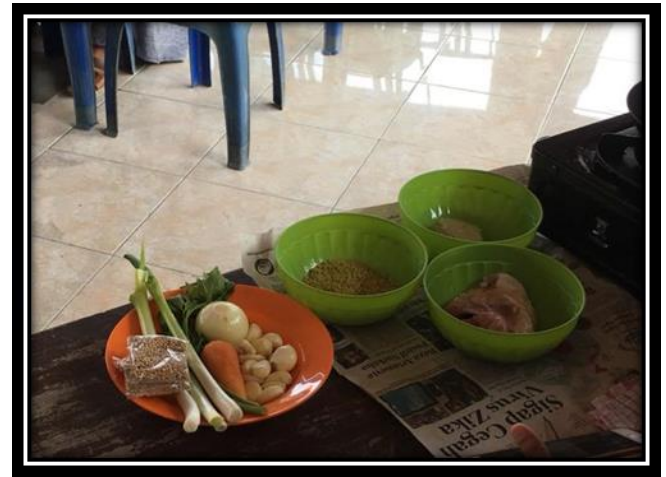

Gambar 1. Persiapan bahan-bahan pembuatan penyedap rasa alternatif

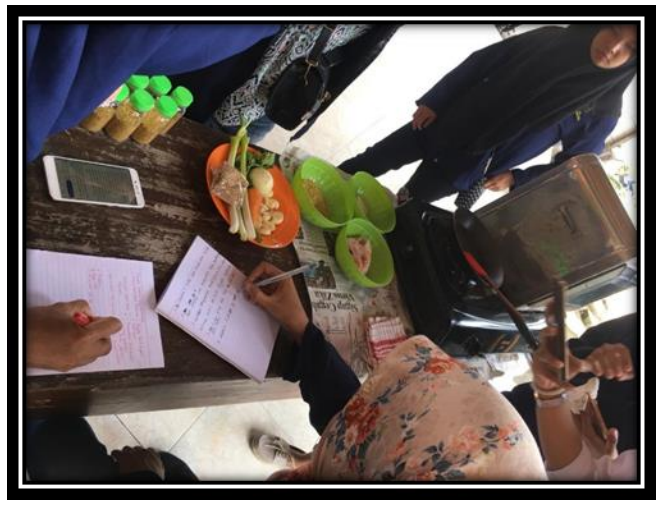

Gambar 2. Tahap Persiapan sosialisasi Pembuatan Penyedap Rasa Alternatif

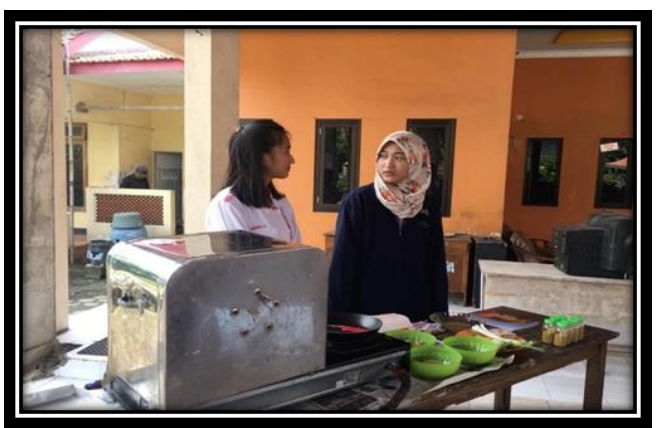

Gambar 3. Tahap Sosialisasi Pembuatan Penyedap Rasa Alternatif

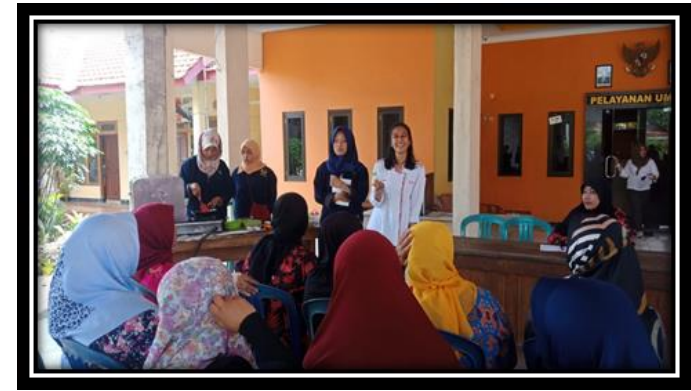

Gambar 4. Tahap Sosialisasi Pembuatan Penyedap Rasa Alternatif

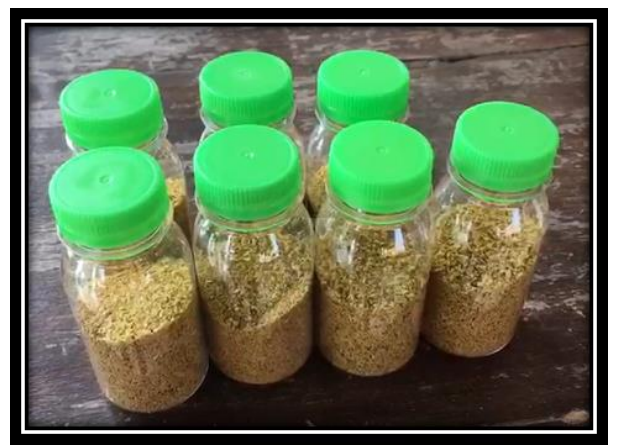

Gambar 5. Pengemasan Penyedap rasa alternative

\section{KESIMPULAN}

Berdasarkan hasil sosialisasi pembuatan penyedap rasa alternatif yang dilalukan di Desa Janti Kecamatan Tulangan, Sidoarjo kepada ibu-ibu penggiat PPK menunjukkan animo peserta sangat tinggi. Kegiatan sosialisasi kepada ibu-ibu penggiat PKK Desa Janti ini juga cukup efektif, karena selain mendapatkan penjelasan yang runtut mengenai proses pembuatan penyedap rasa alternatif berbahan dasar daging ayam tetapi juga mendapat kesempatan untuk menyaksikan langsung proses pembuatannya. Lanjutan dari program sosialisasi ini adalah transfer materi dari ibu-ibu PKK kepada warga masyarakat untuk dapat dipraktikkan dan menjadi alternative penyedap rasa yang sehat dan terjangkau. Program lanjutan ini, dikelola secara mandiri oleh Ibu-ibu PKK Desa Janti dan dipantau oleh perangkat Desa. 


\section{REFERENSI}

Peraturan Menteri Kesehatan RI No. 329/Menkes/Per/XII/1976, Tentang Produksi dan Peredaran Makanan. Edisi II, Jilid II 1976. Departemen Kesehatan RI, Jakarta.

Lisdiana. 2004. Waspada Terhadap Kelebihan dan Kekurangan Gizi. Bandar Lampung.

Nuryani H \& Jinap S. 2010. Soy Sauce and Its Umami Taste: A link From the Past to Current Situation. Journal of Food Science 5(3):71-76.
Malichati, A.R. dan Adi, A.C. 2018. Kaldu Ayam Instan dengan Substitusi Tepung Hati Ayam sebagai Alternatif Bumbu untuk Mencegah Anemia. Amerta Nutrition vol 2 (1) hal 74-82.

Palupi, N.W., Subekah, S., Mayasari, C.A., dan Maslikhah, F. 2015. Kajian Pembuatan Seasoning Alami Cair Berbahan Dasar Jamur Merang (Volvariella volvaceae) dengan Variasi Jumlah Penambahan Glukosa. Repository Unej: http://repository.unej.ac.id/handle/123456789 165414 